American Journal of Agricultural and Biological Sciences 1 (1): 01-05, 2006

ISSN 1557-4989

(c) 2006 Science Publications

\title{
Behaviour Patterns of the Pine Processionary Moth (Thaumetopoea wilkinsoni Tams; Lepidoptera: Thaumetopoeidae)
}

\author{
Ahmad Houri and Dany Doughan \\ Natural Science Division, Lebanese American University, P.O. Box:13-5053 \\ Chouran, Beirut 1102-2801, Lebanon
}

\begin{abstract}
Thaumetopoea wilkinsoni is a serious pest of pine trees, especially the wide-spread Pinus brutia. This infestation has a significant economic impact both in the loss of forest wood growth and in medical expenses for treating related human diseases. This paper presents a detailed study of the behaviour patterns of the moth stage in an attempt to identify best control methods. Several key observations are made towards the moth emergence timing and period of nocturnal activity. Specifically, $92 \%$ of the moths were found to be most active between midnight and 6:00 a.m. Effects of light traps vs. pheromone traps are analyzed and light traps were found to be 15 times more efficient. In addition, $84 \%$ of the captured moths were males and only $16 \%$ were females. Several attempts were made to lure females into traps but were mostly unsuccessful. Finally, moth emergence in relevance to various weather conditions was analyzed and a clear relationship was established where rain appeared to motivate moth emergence. This work has been done over the span of two consecutive years. A clear mode of action is deduced for the best methods of moth control.
\end{abstract}

Key words: Pinus brutia, pheromone, light traps, rain

\section{INTRODUCTION}

The pine processionary moth (Thaumetopoea wilkinsoni) was discovered in the early 1920's by Tams $^{[1]}$ in Cyprus. This moth was later named after Wilkinson $^{[2]}$ and was found to attack specifically two widespread species of pines: Aleppo pine (Pinus halapensis) and calabrian pine (Pinus brutia). It was also observed that Pinus pinea, which carries the commonly eaten pine seeds constituting an important cash crop for the rural areas, was fortunately not attacked by the caterpillar of this moth. Thaumetopoea wilkinsoni belongs to the Thaumetopoea genus, of which four other species are wide spread in Lebanon, namely libanotica, solitaria, processionea and herculeana, attacking various types of plants and trees.

Damage: Besides their defoliation damage, which is the effect most readily observable, the caterpillars have fine hairs on their back containing a protein that causes severe irritation and dermatitis ${ }^{[3-5]}$. These have long affected people in camps or picnics resulting in increased medical treatment costs. The irritating effect of the needles does not end with the caterpillars leaving the nest, because some needles remain attached to the silky fibers of the nest and are released when shaken. Commonly known as "wild pine" in Lebanon, Pinus brutia trees cover a vast area of the Lebanese land, and the effect of the caterpillar on them is most devastating.
Life cycle: $T$. wilkinsoni passes through several stages in its life. After hatching, the larvae consume pine needles as they go through five instars. They build white silken protective nests that help them maintain ideal condition for them to live in. Around the end of March (exact date depends on several conditions like weather and altitude) the caterpillars leave their nests and move down the tree in a processionary fashion. They ultimately dig underground and start pupating. Towards the end of the summer, the mature moths emerge, mate and lay their eggs high on pine trees.

Natural enemies: T. wilkinsoni has several natural enemies varying from parasites to insects and birds $s^{[6,7]}$ that prey on it. Upsetting the natural balance in Lebanon, by bird hunting and wide use of insecticides ${ }^{[8]}$, has left $T$. wilkinsoni with few enemies to control its propagation. Currently, it seems that the only control of the numbers of this pest is the availability of food. This is obvious from the complete defoliation of pine trees towards the end of the caterpillars' growth period.

Control: Methods of control of $T$. wilkinsoni in Lebanon have been lacking the strongly needed widescale application or the general education on the method of application. While Bacillus thuringiensis (B.t.) has been used at various instances, spraying timing and scale have been far from optimal. Application of the female sex pheromone common to $T$. wilkinsoni and $T$. pityocampa species, has been used

Corresponding Author: Ahmad Houri, Natural Science Division, Lebanese American University, P.O. Box:13-5053 Chouran, Beirut 1102-2801, Lebanon 
to capture male moths during the mating season ${ }^{[9,10]}$. Most other methods of control proved to be largely ineffective (e.g spraying with insecticides) or not practical (e.g. nest collection).

Although several studies have been published worldwide on Thaumetopoea pityocampa which has similar preferences to $T$. wilkinsoni $^{[11-15]}$ and specifically on the effect of its hairs ${ }^{[16-21]}$, few scientific studies have emerged regarding $T$. wilkinsoni ${ }^{[6,22,23]}$. Most workers have only casually broached the issue $^{[8,24,25]}$.

The objective of this study was to present detailed information on the behaviour patterns of Thaumetopoea wilkinsoni in its natural habitat, specifically in the moth stage. In addition, the adults' response to various stimuli such as light, pheromones, and weather conditions is analyzed. This understanding aims at providing the necessary information for proper management of this pest in the Mediterranean region.

\section{MATERIALS AND METHODS}

Location: The reported work was conducted in the area of Shouf, Mount Lebanon at an altitude of approximately $450 \mathrm{~m}$. This area is a typical example of the Eastern Mediterranean forests where T. wilkinsoni is widely spread. The area receives around $600 \mathrm{~mm}$ of rain annually, almost exclusively during the winter months. The vegetation is very diverse and two main types of trees are dominant: pine and oak. The pine trees are largely $P$. brutia. The area is close to the village and road, and suffers from recurring severe attacks of $T$. wilkinsoni. The trap and day numbers are arbitrarily used and carry no significance from one figure to the next; Day1 in Fig. 1 is not necessarily the same as Day1 in Fig. 2.

Two types of traps were used: electrical and pheromone funnel traps. T. Pityocampa pheromone funnel traps were purchased from AgriSense-BCS Limited, UK and contain 0.1 to $2.0 \mathrm{mg}$ of pheromones per lure capsule (according to the manufacturer). DDVP insecticidal strips were placed inside the traps. Light traps commonly used for killing mosquitoes were utilized and purchased locally. It consists of a blue fluorescent light bulb surrounded by a high voltage electric wiring lined up approximately $5 \mathrm{~mm}$ apart. We waited until the male moth was being captured by conventional pheromone traps before initiating this study. The initial date when the first moth was captured was September $5^{\text {th }}$. A control pheromone trap was maintained to consistently indicate the extent of moth presence on the specified date. Numbers of moths captured indicate the number of dead moths found in the trap, exclusive of those that might have been able to escape and those that might have fallen outside the collection container. All traps were placed between 2 and 4 meters high, as oviposition does not normally happen below this height ${ }^{[6]}$. Weather data was collected by a Weather Monitor II station purchased from Davis instruments.

\section{RESULTS AND DISCUSSION:}

Initial testing for the existence of the male moth: Two funnel traps were placed near an infected area (1north, 2-south) and the pheromone capsules were installed. Table I shows the moths captured in this initial testing stage. Trap 2 is closer to the road and the forest edge; accordingly it generally captured more moths. Similar observations indicating the tendency of moths to prefer isolated stands or forests edges have been previously reported ${ }^{[26,27]}$.

\begin{tabular}{lll} 
Table 1: & Moth capture at different sites by pheromone traps \\
\hline Day & Trap 1 & Trap 2 \\
\hline 1 & 4 & 16 \\
2 & 6 & 19 \\
3 & 10 & 7 \\
4 & 9 & 14 \\
\hline
\end{tabular}

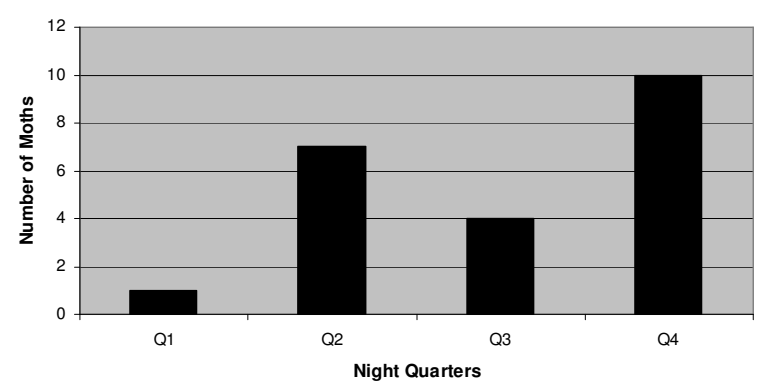

Fig. 1: Moths captured by pheromone traps

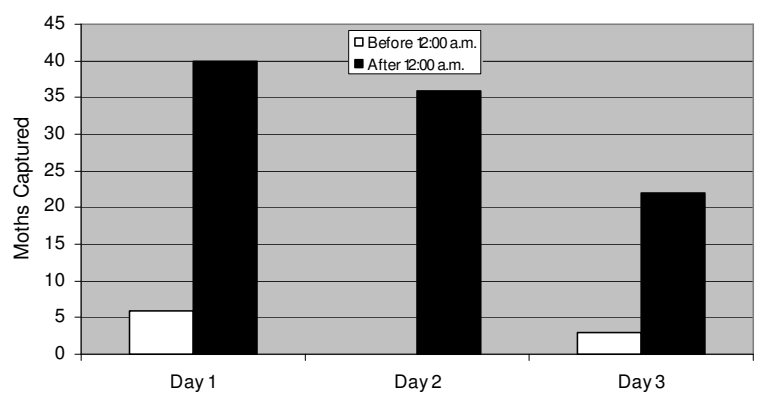

Fig. 2: Moths captured before and after midnight

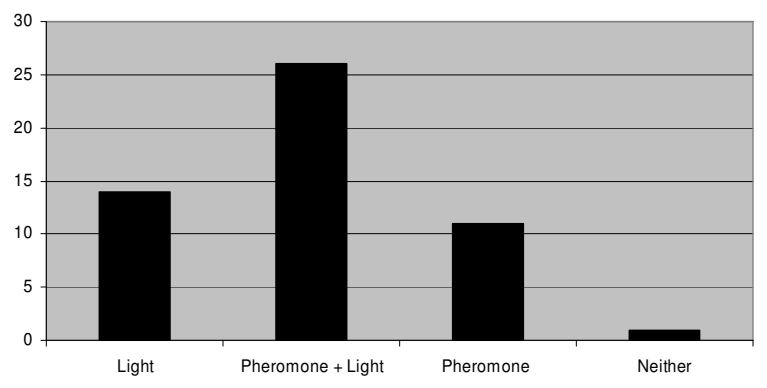

Fig. 3: Moths captured by various techniques

Time of activity determination: With the establishment of moth presence, the second phase of the 
investigation involved determining the time of moth activity. Traps one and two were placed around thirty meters apart near a previously heavily infested area. The traps were checked daily in the morning and the evening. Data obtained indicated that over the period of 8 days, 37 and 48 moths were captured by traps 1 and 2 respectively during the night while none were captured during the day.

We have also attempted to determine the time of highest activity for the moths by checking the rate of capture, by pheromone traps, at three-hour intervals throughout the night. This checking was done over five consecutive nights. Sunset at the time was around 7:00 p.m. Figure 1 shows that the moths are more active in the later part of the night rather than the earlier part.

However, the relative low numbers captured, despite the use of a five-day total, made it hard to come up with concrete conclusions. Accordingly, in a subsequent year, six light traps were turned on all night long (as electricity became available in the area) and Fig. 2 illustrates the pre and post midnight numbers of captured moths. A total of 9 moths were captured before 12:00 midnight and 98 after that time, which indicates that $92 \%$ of the activity occurred after midnight. This is in line with observations made on a similar species ${ }^{[12]}, T$. pityocampa, where it has been indicated that few hours are needed after sunset for the adult moths to gain enough strength in their wings for flight.

Female moth trapping attempts: Several attempts were undertaken to lure the female moths selectively. The theory behind this work was trying to identify the potential aromatic components that might be luring the female moths to lay their eggs in $P$. brutia but not $P$. pinea. Tiberi ${ }^{[28]}$ have indicated the potential role of Limonene, which is abundant in $P$. pinea, in repelling the moths of the close relative Thaumetopoea pityocampa. Branch and needle oil extracts were obtained by steam distillation and placed in funnel traps to check their efficiencies in attracting female moths. None were trapped. Attempts with other types of extracts such as pine resin, $\alpha$-pinene ( $\mathrm{R}$ and $\mathrm{S}$ forms), and commercial forms of pine oil met similar failure. Further research is certainly needed to identify the factors controlling the female moth's behaviour.

Light traps vs. pheromone traps: Effectiveness of the pheromone and its advantage, if any, over regular light trapping methods was assessed by monitoring the number of moths trapped by light with and without the assistance of a pheromone capsule. To insure maximum similarity between the studied cases, the pheromone was placed next to the blue light in the electric trap, or the light was removed from the electric traps and replaced with the pheromone capsule, or light bulb was simply removed. The numbers indicated refer to the moths trapped over the period of seven days within 2

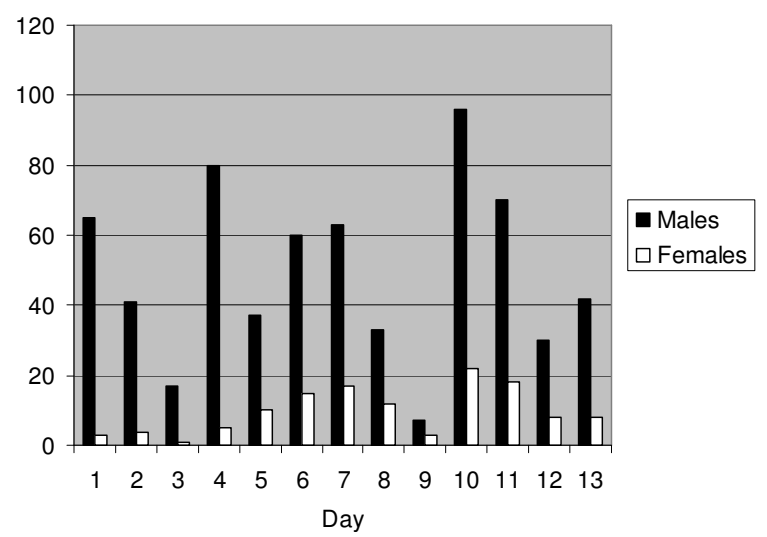

Fig. 4: Male vs. female moths captured

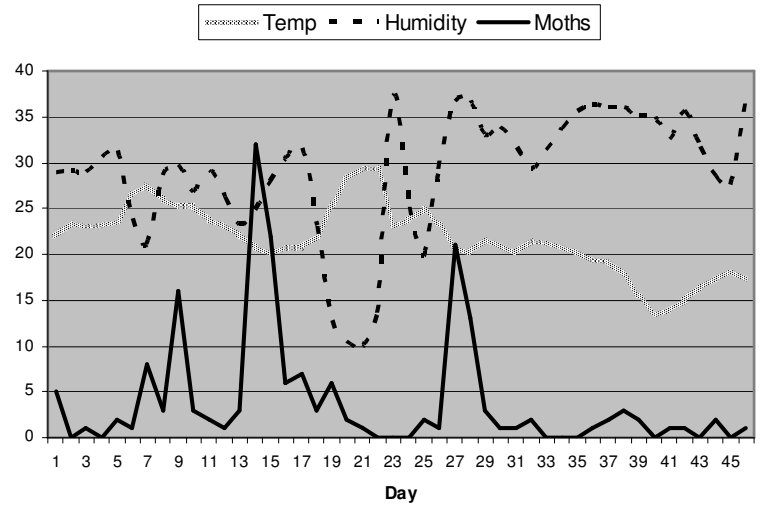

Fig. 5: Moth emergence vs. temperature and humidity

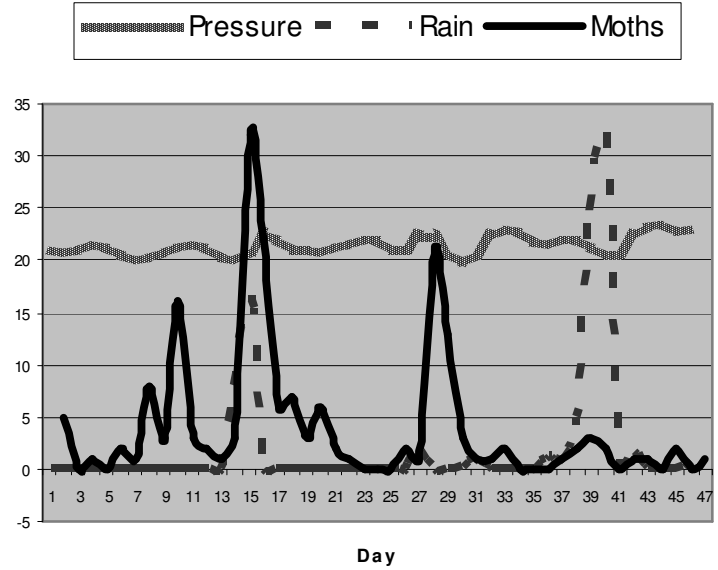

Fig. 6: Moth emergence vs. pressure and rain

hours after sunset. Constraints on the availability of electricity at the site in the first year of work necessitated such a measure.

In an attempt to enhance moth-capturing capability, the effect of electric light color on the tendency to attract the moth was also studied over 10 days. The results clearly indicate that the moth is attracted to blue light (33 captured) more than it is to yellow light (7 captured). Counts were again taken two hours after 
sunset due to restrictions on the availability of electricity in the region.

While a significant advantage of light over pheromone trapping was not established by the above figures, further study was undertaken in the following year when electricity became available all the time. The objective was to determine which method was more efficient and whether pheromone traps were worth the cost. Over a period of 47 days, the pheromone trap captured 95 moths while the light trap captured 1414 moths showing a clear advantage of light traps, almost 15 times better.

It remained to be analyzed whether the observed patterns were due to excessive female capturing by light traps. The moths were categorized and Fig. 4 clearly indicates that light traps preferentially trap male moths. Collateral damage to other moth species, while minimal, has not been assessed in detail, and would be the objective of a future study. On average the moths trapped were $84 \%$ male and $16 \%$ female. The maximum male percentage at any given night was $94 \%$ and the minimum was $70 \%$. The data was collected over a period of 13 nights. A total of 641 males and 126 females were captured.

Effect of weather on moth emergence: The trapping efficiency showed an interesting relationship with the weather. Figure 5 indicates the relationship between number of trapped moths (in a funnel trap, first year) and the average temperature and humidity at a given date. No clear relationship is readily visible. However, when barometric pressure and rainfall were analyzed with respect to moth capture (Fig. 6), results clearly indicate that rain has a direct effect on the emergence of the moths. The presence of rain seems to be more significant than its amount. After October $15^{\text {th }}$ few moths remain and that is why further rain after day 35 does not result in any further increase in numbers of moths captured.

\section{CONCLUSION}

Based on the above collected data, several conclusions are made regarding the behaviour patterns of the pine processionary moth. First, the moth is nocturnal with $92 \%$ of the activity occurring after midnight. Second, the moth prefers blue light to yellow light; in addition, light traps are far cheaper and 15 times more effective than pheromone traps. However, the use of these light traps may carry significant collateral impact on other local species. While few other species were captured in our experiments, no attempt was made to identify them. Further study on other nocturnal species active in that region and time is warranted. $84 \%$ of the moths captured by light traps were males. Third, pine oil, whether commercial or extracted from the pine tree itself, is ineffective in attracting the female moth. Two reasons may be suggested to account for this fact: a. the female is not affected by the pine scent (chemistry) but rather by the morphology of the needles or b. the pine oil's scent fades when compared to the scent of pine already present in the surrounding forests. Female mobility before ovipositing is supported by the fact that remote and cleaned forests are infected by the pest present in neighboring forests. The above fact, in addition to previous reports of flights lasting 2-3 hours ${ }^{[12]}$ for $T$. pityocampa, indicate that lack of mobility does not necessarily account for the lack of female capture. The capture of females with significant numbers of eggs in their abdomen tends to favor the observations of Demolin over the report by Schmidt ${ }^{[13]}$. Observations made by Demolin ${ }^{[12]}$ indicate increased male sensitivity towards light for $T$. pityocampa and that could be the case for $T$. wilkinsoni also.

Fourth, the moth emergence is strongly affected by weather conditions. As can be observed from the data collected, emergence is directly related to precipitation. Demolin $^{[12]}$ reported a potential correlation with barometric pressure but that is not the case with $T$. wilkinsoni. This observation can be used to predict moth emergence in the future (may be even without the use of traps). This is the first report of such an observation and could serve to explain the lack of moth hatching in laboratory samples $(<10 \%)$ reported for $T$. pityocampa ${ }^{[14]}$. Trapping moths should be initiated in the beginning of September and extra effort should be done on nights following rainy days. Finally, the moths had a mild sensitizing effect and caused some itching for the persons handling them; however, this is much milder than that caused by the caterpillar

A detailed study of the behaviour patterns of the pine processionary moth in the moth stage has been presented. Methods of improving capturing efficiency have been suggested and several new observations were reported.

\section{ACKNOWLEDGEMENTS}

This work has been supported by the Lebanese American University Research Grant number (URC c1999-23 and URC-f1999-06). Experiments described comply with the current laws of Lebanon.

\section{REFERENCES}

1. Tams, W.H.T., 1924-1925: A New Processionary Moth (Notodontidae) Injurious to Pine Trees in Cyprus. Bull. Ent. Res, 15: 293-294.

2. Wilkinson, D.S., 1926-1927: The Cyprus Processionary Caterpillar. (Thaumetopoea wilkinsoni, Tams.) Bull. Ent. Res., 17: 163-182.

3. Finkelstein, Y., E.B. Raikhlin and U. Taitelman U, 1988: Systematic Manifestation of Erucism: A case report. Vet. Hum. Toxicol., 30: 573-4. 
4. Bessler, E., B. Biedner and Y. Yassur, 1987: Thaumetopoea wilkinsoni Blepharconjuctivitis. Am. J. Ophthalmol., 103: 117-8.

5. Ziprkowski, L. and F. Rolant, 1972: Study of Toxins from Poison Hairs of Thaumetopoea wilkinsoni Caterpillars. J. Invest. Dermatol., 58: 247-277.

6. Arafat, M.A., 1965. The Biology and Economic Damage of the Cyprus Pine Processionary Moth Thaumetopoea Wilkinsoni, Tams. Thesis. Dept. of Agricultural Sciences at the American University of Beirut. Lebanon.

7. Tohme, G. and H. Tohme, 1986: Birds of Lebanon. Lebanese University Publications, Natural Science Division. Beirut, Lebanon.

8. Habre, R.M., 1992: Nature of Lebanon: The Human Environment. UNICEF Peace Education Program. Beirut, Lebanon pp: 74-82.

9. Halperin, J., Y. Golan, C. Descoins, B. Frerot and A. Shni, 1981: Preliminary trials on the attraction of Thaumetopoea wilkinsoni Tams. to the synthesized sex pheromone of Thaumetopoea pityocampa Schiff. La Yaaran. The Forester, 31: 24-31.

10. Shani, A., 1998. Integrated pest management using pheromones. Chemtech, 28: 30-35.

11. Denneulin, J.C. and M. Lamy, 1977: Effects of dimilin, a chitin inhibitor 1-(4 chlorophenyl)-3-(2-6 difluorobenzoyl) urea on the oenocytes and molting in the processionary caterpillar (Thaumetopoea pityocampa Schiff.) (Lepidoptera). Ann. Endocrinol. Paris, 38: 405-6.

12. Demolin, G., 1969. Comportement des Adultes de Thaumetopoea Pityocampa Schiff. Dispersion Spatiale, Importance Ecologique. Ann. Sc. Forest., 26: 81-102.

13. Schmidt, G.H., 1990. The egg batch of Thaumetopoea pityocampa (Den. \& Schiff.) (Lep., Thaumetopoeidae): Structure, hatching of the larvae and parasitism in Greece. J. Appl. Ent., 110: 217-228

14. Devkota, B. and G.H. Schmidt, 1990: Larval development of Thaumetopoea pityocampa (Den. \& Schiff.) (Lep., Thaumetopoeidae) from Greece as influenced by different host plants under laboratory condition. J. Appl. Ent,. 109: 321-330

15. Hodar, J.A., R. Zamora and J. Castro, 2002: Host utilization by moth and larval survival of pine processionary caterpillar Thaumetopoea pityocampa in relation to food quality in three Pinus species. Ecolog. Entomol., 27, 291-301.

16. Lamy, M., M.H. Pasturead, F. Novak, G. Ducombs, P. Vincendeau, J. Maleville and L. Texier, 1986. Thaumetopoein: an urticating protein from the hairs and integument of the pine processionary caterpillar (Thaumetopoea pityocampa Schiff., Lepidoptera, Thaumetopoeidae). Toxicon, 24: 347-56.
17. Lamy, M., P. Vincendeau, G. Ducombs and M.H .Pastureau, 1983. Irritating substance extracted from the Thaumetopoea pityocampa caterpillar, mechanism of action. Experientia, 39: 299.

18. Lamy, M., M.H. Pasturead and G. Ducombs, 1985. Thaumetopoein: an urticating protein from the hairs and integument of the pine processionary caterpillar (Thaumetopoea pityocampa Schiff., Lepidoptera, Thaumetopoeidae). C. R. Acad. Sci. III, 301: 173-6.

19. Werno, J. and M. Lamy, 1990. Atmospheric pollution of animal origin: the urticating hairs of the processionary caterpillar (Thaumetopoea pityocampa Schiff.) (Insects, Lepidoptera) C. R. Acad. Sci. III, 310: 325-31.

20. Ducombs, G., M. Lamy, M. Michel, R. Pradinaud, P. Jamet, P. Vincendeau, J. Maleville and L. Texier, 1979. Thaumetopoea pityocampa caterpillar and man. Morphology of its venom apparatus. Epidemiological investigation. Ann. Dermatol. Venereol., 106: 769-78.

21. Angebault, J.Y., 1974. Ocular accidents due to hairs of the pine tree processional caterpillar (Thaumetopoea pityocampa). Bull. Soc. Ophtalmol. Fr., 74: 373-80.

22. Tohme, H., G. Tohme and A. Hossari, 1981: Etude de quelque particularites du cycle biologique de Thaumetopoea wilkinsoni et de l'influence de certains facteurs ecologiques sur ce cycle. Ext. du Bull. Soc. Hist. Nat. Toulouse, 3: 1234.

23. Tohme, H. and G. Tohme, 1982: Action de quelque especes de fourmis sur la chenille processionaire Thaumetopoea wilkinsoni au Liban et leur comportement en presence de cette chenille. Bull. Soc. Entom. de France, 87.

24. Talhouk, A., 1997. Insects' role in the Environment: Diversity of Moths in Lebanon. Fares Foundation. Beirut, Lebanon, pp: 58, 141-142.

25. Tohme, G. and H. Tohme, 1985. Ecology of Lebanon. Lebanese University Publications, Natural Science Division. Beirut, Lebanon, pp: 192-194.

26. Tiberi, R., 1983. Sulla distribuzione della ovature di Thametopoea pityocampa (Den. \& Schiff.) in un giovane impianto di Pinus piniaster e $P$. insignis. Redia, 66: 603-614.

27. Mendel, Z., 1988. Host selection by the pine processionary caterpillar Thaumetopoea wilkinsoni. Phytoparasitica, 16: 101-108

28. Tiberi, R., A. Niccoli, M. Curini, F. Epifano, M.C. Marcotullio and O. Rosati, 1999. The role of the monoterpene composition in Pinus spp. needles in host host selection of the pine processionary caterpillar, Thaumetopoea pityocampa. Phytoparasitica, 27: 263-272. 